Article

\title{
Children with Clinical Psychological Symptoms: The Discriminant Role of Conjugality, Coparenting and Parenting
}

\author{
Clarisse Mosmann ${ }^{1}$ \\ Orcid.org/0000-0002-9275-1105 \\ Crístofer Batista da Costa ${ }^{1, *}$ \\ Orcid.org/0000-0002-1307-1436 \\ Allana Gessiele Mello da Silva ${ }^{1}$ \\ Orcid.org/0000-0002- 3086-2109 \\ Susana Konig Luz ${ }^{2}$ \\ Orcid.org/0000-0001-9508-1699 \\ ${ }^{1}$ Universidade do Vale do Rio dos Sinos, São Leopoldo, RS, Brasil \\ ${ }^{2}$ Faculdade Meridional, Passo Fundo, RS, Brasil
}

\begin{abstract}
Studies indicate that the mental health of children suffer positive and negative reverberations not only from the parent-child relationship, but also from marital and coparenting aspects. However, the nature and magnitude of these associations, when considered together, are not yet sufficiently understood, especially in the national context. This study aims to investigate in children and adolescents with and without clinical psychological symptoms, the discriminant role of the variables of their parent's marital, parental and coparental relations. The sample consists of 200 participants, with children 4-18 years old in a steady relationship and cohabiting with the offspring. Through discriminating statistical analysis the variables coparental competition, intrusiveness of parenting, child exposure to coparenting conflict, and marital conflict were identified as discriminant of children with clinical symptoms. The results indicate that the coparental subsystem prevails in this relationship, however the three dimensions analyzed interact interdependently in the psychological adjustment of children.
\end{abstract}

Keywords: Children, adolescents, symptoms, family relations.

\section{Filhos com Sintomas Psicológicos Clínicos: Papel Discriminante da Conjugalidade, Coparentalidade e Parentalidade}

\section{Resumo}

Estudos indicam que a saúde mental dos filhos sofre reverberações positivas e negativas não somente da relação pais-filhos, mas também de aspectos da conjugalidade e da coparentalidade. Entretanto, a natureza

Mailing address: Universidade do Vale do Rio dos Sinos, Programa de Pós-Graduação em Psicologia, Av. Unisinos, 950, São Leopoldo, RS, Brazil 93022-000. Phone: (51) 3591-1207. E-mail: cristoferbatistadacosta@ gmail.com and allanagmsilva@gmail.com 
e a magnitude dessas associações, quando analisadas em conjunto, ainda não foram suficientemente compreendidas, especialmente no contexto nacional. Nesse sentido, objetivou-se investigar em crianças e adolescentes com e sem sintomas psicológicos clínicos, qual o papel discriminante das variáveis da relação conjugal, coparental e parental de seus pais. A amostra foi composta por 200 participantes, com filhos de 4 a 18 anos, casados e coabitando com a prole. Através de análise estatística discriminante identificou-se as variáveis competição coparental, prática parental de intrusividade, exposição do filho ao conflito coparental e conflito conjugal como discriminante dos filhos com sintomas clínicos. Os resultados apontam que o subsistema coparental prepondera nesta relação, entretanto as três dimensões analisadas interagem de forma interdependente no ajustamento psicológico dos filhos.

Palavras-chave: Crianças, adolescentes, sintomas, relações familiares.

\section{Hijos con Síntomas Psicológicos Clínicos: El Rol Discriminante de la Conyugalidad, Coparentalidad y Parentalidad}

\section{Resumen}

La salud mental de niños sufre repercusiones positivas y negativas no sólo de la relación padres e hijos, sino también del matrimonio y de la coparentalidad. Sin embargo, la naturaleza y magnitud de estas asociaciones, cuando se consideran conjuntamente, no están aun suficientemente comprendidas, especialmente en el contexto nacional. Se objetivó investigar en niños y adolescentes con y sin síntomas psicológicos clínicos, el rol discriminante de las variables de la relación matrimonial, parental y coparental. La muestra fueron 200 participantes, con niños de 4-18 años, en relación estable y que cohabitan con estos. El análisis discriminante mostró las variables competencia coparental, práctica parental de intrusión, exposición del niño al conflicto coparental y el conflicto conyugal como discriminantes de los niños con síntomas clínicos. Los resultados indican que el subsistema coparental prevalece en esta relación, sin embargo, las tres dimensiones analizadas interactúan de manera interdependiente en el ajuste psicológico de niños.

Palabras clave: Niños, adolescentes, síntomas, relaciones familiares.

Research concerning the impacts of the characteristics of a family's functioning on child development has steadily advanced over the last two decades. One perceives that children's mental health and behavior are positively and negatively influenced not only by the parent-child relationship, but also by the characteristics of the parents' conjugality and coparenting (Einsfeld, Silva, Trindade, \& Mosmann, 2012; Mosmann, Costa, Einsfeld, Silva, \& Koch, 2017; Silva \& Mosmann, 2014).

Feinberg (2003) defines coparenting as parents' joint and mutual participation in their children's education, rearing and life decisions. Nonetheless, this is a complex construct that is not limited to father-mother dyads alone, but also involves all relationships between at least two individuals who, by mutual accord or due to social norms, assume joint responsibility for the wellbeing of at least one child (Marsanic \& Kusmic, 2013). In nuclear families that have not undergone the divorce of the parents, coparenting is dynamically interconnected with other familial subsystems, namely conjugality and parenting (Lamela, Nunes-Costa, \& Figueiredo, 2010).

Studies concerning the impacts of the characteristics of a family's functioning on child development center principally on the correlations between conjugality, parenting and coparenting, aiming at discovering the particular variables that generate the means of interaction between these subsystems (Morril, Hines, Mahmood, \& Cordova, 2010). Such academic endeavors are founded upon an attempt to more precisely identify each family subsystem's importance and role in such interactions, data that contributes to promoting higher quality marital relationships and serves as a source of support for marital 
partners in terms of parenting and coparenting and, consequently, as a form of safeguarding the development of their children (Mosel, Wagner, \& Sarriera, 2008; Wagner \& Mosmann, 2009).

It is presumed that a marital relationship's quality influences the manner in which parents deal with child problems because their aptitude for resolving marital conflicts is manifested in their parenting practices. This concept refers to the parent-child spillover hypothesis (Erel \& Burman, 1995), which postulates that a marriage's characteristics spill over to parenthood (Merrifield \& Gamble, 2012), negatively or positively affecting child development and thus presenting a risk or protective factor for the child (Christopher, Umemura, Mann, Jacobvitz, \& Hazen, 2015; Mosmann et al., 2008; Schmidt, Crepaldi, Vieira, \& Moré, 2011).

Along these lines, a study conducted in the United States examined 149 families with children between 3 and 6 years of age and substantiated the spillover hypothesis (Stroud, Wilson, Durbin, \& Mendelsohn, 2011). Spillover occurs in various familial subsystems, but the consequences differ depending upon the way in which the mother-father-child behavior is examined. The U.S. study's principal results revealed that the marital subsystem influenced affection in the triadic interactions and in the responses of fathers and children in dyadic interactions in relation to the mothers. The spillover effects were the same for boys and girls, yet the spillover to parental hostility in the triadic interactions was limited to families raising girls.

The parents' gender also influenced the correlations between marital functioning and parent-child interactions. The spillover of marital characteristics occurred in an affective response of the fathers and in an affective response of the children to their mothers, but not as a response of the mothers or children to the fathers. The spillover's effects were more substantial for the fathers' responses than for the mothers' responses and were stronger for the children's responses to their mothers than to their fathers (Stroud et al., 2011).

In addition to the above, parenting practices are among the principal variables related to children's socio-emotional development, parent-child relationships, and the family environment's equilibrium during the various stages of the family's life cycle. Nevertheless, there still is uncertainty as to what is known about the factors that most significantly influence parenting practices. The most commonly highlighted factors are the following: the birth order and number of children in the family, the parents' personalities and mental health, the quality of the marital relationship, the parents' own childhood experiences, gender issues, the parents' schooling level, the children's traits and behaviors, the social context, the moment in the family's life cycle, and the spouses' division of parenting responsibilities (Bolsoni-Silva, Paiva, \& Barbosa, 2009; Freitas \& Piccinini, 2010; Laxman et al., 2013; Teixeira, Oliveira, \& Wottrich, 2006).

Although a significant correlation between the aforementioned variables has been substantiated empirically, there is no consensus as to the nature and scale of such correlations, i.e. as to whether or not such correlations are the result of cause and effect and are capable of being trimmed down to a small number of variables (Zahn-Waxler, Shirtcliff, \& Marceau, 2008). Nonetheless, one must choose the variables that are to be analyzed in each study so as to identify those that exhibit greater predictive power in terms of child adjustment.

When the focus of the research is on the couple, one observes, for example, that marital disagreement and agreement are variables that influence parenting (Engle \& McElwain, 2013), a factor that can affect parent-child negotiations and coparenting agreements. Once again, a couple's interaction, as parents, can be a factor that determines the household environment's protection from or exposure to risks (Portugal \& Isabel, 2013). One perceives that there are countless correlations and variables interacting between the various family subsystems and that it is the researchers' responsibility to select, based on the empirical evidence and aim of the study, those which can help explain the phenomenon.

A study involving 551 American parents examined the correlations between marital conflicts, parenting and child adjustment (Gerard, 
Krishnakumar, \& Buheler, 2006). The survey's results revealed a correlation both between marital conflicts and parental hostility and between low marital conflict levels and high parental involvement levels, indicating that children sense the effects of the negative and positive aspects of conjugality.

More specifically, the above study revealed that parents with intense marital conflicts seem to exhibit less tolerance for handling the challenges their children daily pose to the family system. Such frustration is manifested in the parents' lack of patience toward their children's behavior and demands, which is expressed through low responsiveness and childrearing strategies based on coercive control. Such a dynamic resonates longitudinally in children's externalization problems (Gerard et al., 2006). In an analogous manner, in the case of couples with strong marital conflicts, low responsiveness and few demands, the context will be highly predictive of internalization problems (Davies, Harold, Goeke-Morey, \& Cummings, 2002).

Along these lines, Mosmann et al. (2008) confirmed the predictive value of the positive and negative traits of each spouse with respect to the marital and parental subsystems and family dynamics. 149 couples with teenage children were surveyed, establishing a contrasting comparison between the variables of the marital relationships and the parents' childrearing styles. The results showed that couples with higher levels of cohesion, adaptability and marital satisfaction typify the responsive parenting style, which is exemplified by emotional intimacy. The gender, workload and conflicts/antagonism variables characterized couples with nonresponsive parenting styles, and the personal income and time spent with the children variables, distinguished the negligent and authoritarian parenting styles, respectively.

The correlation between conjugality, parenting and child development was the focus of a systematic review of Brazilian and international scientific articles published from 1980 to 2010 (Schmidt et al., 2011). The results of the review pointed to a significant correlation between conjugality and a child's temperament. The high- est levels of marital quality and marital adjustment were predictive of collaborative parenting practices, even when the parents described their child's temperament as difficult. Overall, the researchers reported results that are correlated, yet in two directions: negative influences of the low marital quality, of the conflicts and of the parenting on the development of their children, as well as the difficult temperament of their children, as a factor that impairs the marital relationship and parenting practices, thus indicating the bidirectional character of such correlations.

Along these lines, and without considering marital relationship variables, Bolsoni-Silva et al. (2009) observed that parenting practices and child behavior mutually influence each other and eventually determine the predominant form of child-caregiver interaction. According to the authors, coercive parenting practices provoke correspondingly negative responses on the part of the children and lead to the manifestation of symptoms of externalization and internalization, which in turn cause parental stress and frustration.

In addition to studies and debates concerning conjugality's impacts on parenting practices, child development and family dynamics, research into the coparenting subsystem has led to advances in the area (Blandon, Scrimgeour, Stifter, \& Buss, 2014; Christopher et al., 2015; Holland \& McElwain, 2013; Laxman et al., 2013; Merrifield \& Gamble, 2012; Pedro, Ribeiro, \& Shelton, 2012; Riina \& McHale, 2015). In the Brazilian literature, efforts have been made to comprehend coparenting within the divorce context (Lamela, Figueiredo, \& Bastos, 2013), yet within the nuclear family context, it has hardly been studied, although it has already been proven to be an extremely important potential link in the chain of correlation between conjugality and parenting (Einsfeld et al., 2012, Mosmann et al., 2017; Silva \& Mosmann, 2014). That is because coparenting is a unique element of the marital relationship, bearing in mind that parents can either cooperate or wage an endless battle in relation to parenting practices (Feinberg, 2003).

Worldwide studies have shown that children's development could be explained better if 
we were to also include coparenting in the analysis of such associations, considering its impact on systemic family relationships, rather than considering marital and parenting quality alone (Kwon, Jeon, \& Elicker, 2013; Mendez, Loker, Fefer, Wolgemuth, \& Mann, 2015; Scrimgeour, Blandon, Stifter, \& Buss, 2013; Silva \& Mosmann, 2014), and that coparenting is an important factor in child development, from childhood to adolescence (Christopher et al., 2015; Laxman et al., 2013; Mendez et al., 2015). Research in this area reveals a need for studies that question whether coparenting, in the long term, could serve as a mediator between negative aspects of a marital relationship, such as low levels of cohesion and adjustment, high degrees of conflict and of non-settlement of such conflicts, and child development problems (Jia, Kotila, \& SchoppeSullivan, 2012; Sbicigo \& Dell'Aglio, 2012).

Furthermore, there is longitudinal empirical evidence to the effect that coparenting and family functioning are related to the development of children at different ages (Christopher et al., 2015; Laxman et al., 2013; Riina \& McHale, 2013). By and large, the evidence reveals that children's behavior is influenced not only by parent-child relationships, but also by coparenting, when spouses fail to support each other and manifest contrary parenting methods in front of their children.

The literature we found indicates that variables of all three subsystems (marital, parental and coparental) actively contribute to forming a protective family system aimed at guaranteeing healthy child development. Nonetheless, in order to acquire a better understanding of this subject within the Brazilian context, one must examine all three dimensions together (conjugality, parenthood and coparenting; Majdandzic, Vente, Feinberg, Aktar, \& Bögels, 2012) because the results of analyses of the three subsystems' variables are reported separately in the literature.

Accordingly, we sought to examine children and adolescents with and without clinical psychological symptoms in order to discover the discriminant role of the variables of their parents' marital, parental and coparental rela- tionships. Our guiding hypothesis was that positive coparenting variables (mutual accord and support, shared responsibilities, and coparental approval) would exhibit stronger discriminant power for the nonclinical group with respect to positive parenting practices (supervising child behavior; offering emotional support and affection; encouraging autonomy; requiring responsible conduct) and marital cohesion and adaptability (Christopher et al., 2015; Laxman et al., 2013; Riina \& McHale, 2013). We also conjectured that negative coparenting variables (competing and exposing children to coparenting disagreements) would exhibit stronger discriminant power for the clinical group with respect to marital conflicts and negative parenting practices (intrusiveness and punitive control; Jia et al., 2012; Sbicigo \& Dell'Aglio, 2012).

\section{Method}

\section{Delineation}

The present research is a quantitative study of an exploratory, descriptive, comparative and transverse nature.

\section{Sample}

The present study enjoyed the participation of 200 individuals (100 men and 100 women). The sample's calculations were based on Hair, Anderson, Tatham and Black's suggestions (2005) for performing discriminant analyses, which establish 5 observations for each independent variable. Our study consisted of 15 independent variables, encompassing at least 75 individuals. Furthermore, each group had to have at least 20 observations. The clinical group was made up of 20 children; and the nonclinical group, 180. Our criteria for inclusion called for men and women (with at least one child aged 4-18) who were married or in a civil union and were living together with their child in a metropolitan region or inland area in the state of Rio Grande do Sul.

\section{Instruments}

Sociodemographic Questionnaire. This questionnaire consisted of thirteen closed-ended 
questions that enabled us to ascertain the research participants' sociodemographic data.

Family Adaptability and Cohesion Evaluation Scale [FACES III] (Olson, 1986; validated by Falceto, 1997). This twenty-item scale is scored according to a five-point Likert scale (almost never, at least once, sometimes, frequently, almost always). The Cronbach's alphas found in other studies (Felgosa, 2013; Mosmann et al., 2008) were considered satisfactory, namely 0.80 and 0.78 for cohesion and 0.67 and 0.72 for adaptability, respectively. In the present study, the coefficients were 0.68 for cohesion and 0.83 for adaptability.

Marital Conflict Scale (Buehler \& Gerard, 2002; adapted by Mosmann et al., 2008). This nine-item scale is subdivided into two subscales. The first subscale, entitled "misunderstandingbased conflicts," consists of 6 items that are scored according to a 6-point Likert scale (never, once a month or less, several times a month, approximately once a week, several times a week, almost every day), whose ratings refer to the frequency with which the examinees had disagreements with their partners over the last year. The second subscale, entitled "aggression-based conflicts," consists of three items that are scored according to a five-point Likert scale (never, rarely, sometimes, frequently, always). Employing the adapted version of the scale (Mosmann et al., 2008), the present study yielded Cronbach's alphas of 0.71 and 0.78 .

Parenting Style Scale. Developed by Teixeira et al. (2006), this scale consists of 27 items and of six dimensions (emotional support, punitive control, encouragement of autonomy, intrusiveness, supervision of behavior, and insistence on responsibility) that are scored according to a five-point Likert scale that ranges between "almost never or very rarely" and "usually or frequently." In both the original study and the present study, the Cronbach's alphas (internal reliability) that were obtained, respectively, were 0.89 and 0.89 (emotional support); 0.78 and 0.74 (punitive control); 0.76 and 0.65 (encouragement of autonomy); 0.67 and 0.63 (intrusiveness); 0.77 and 0.77 (supervision of behavior); 0.70 and 0.61 (insistence on responsibility).

Coparenting Relationship Scale [CRS] (Feinberg, Brawn, \& Kan, 2012; translated and adapted for the present study). This scale consists of 35 items subdivided into two separate subscales that measure seven coparenting dimensions: coparental agreement, coparental closeness, exposure to coparenting conflicts, coparental support, coparental competition, approval of the other spouse's parenting, and coparenting responsibility sharing. The items are scored according to a six-point Likert scale, which varies between "not true about us" and "very true about us" for the first subscale; and between "never" and "very frequently," for the second. In both the original study and the present study, the Cronbach's alphas (internal reliability) that were obtained, respectively, were 0.74 and 0.68 (coparental agreement), 0.81 and 0.47 (coparental closeness), 0.89 and 0.78 (exposure to coparenting conflicts), 0.87 and 0.81 (coparental support), 0.85 and 0.85 (coparental competition), and 0.83 and 0.63 (approval of the other spouse's parenting style). The coparenting responsibility sharing dimension involved two items alone, which is why its internal consistency could not be measured. In light of the of the coparental closeness dimension's low internal consistency, it was excluded from the present study.

Child Behavior Checklist [CBCL] (Achenbach \& Rescorla, 2001; Cronbach's alpha of 0.97 for the scale's total internal consistency). This instrument presents preliminary validity evidence for the Brazilian population (Rocha et al., 2013). It is a 138-item scale that assesses children's emotional and behavioral problems, and is designed for fathers/mothers or caregivers. 20 of the 138 items evaluate children's social skills, and the other 118 assess their behavioral problems. The questionnaire's items list a series of desirable and undesirable behaviors according to a three-point Likert scale, whereby 0 indicates not true, 1 denotes true or occasionally true, and 2 indicates very true or frequently true. The internal reliability coefficients we ob- 
tained were the following: anxiety/depression (0.77), withdrawal (0.71), somatic disorders $(0.67)$, social difficulties $(0.72)$, delinquent behavior (0.73) cognitive difficulties (0.66), aggressive behavior $(0.82)$ concentration difficulties $(0.82)$ and other problems $(0.61)$.

\section{Procedures}

Data Collection. We formed our sample via convenience sampling, that is, we selected the population's individuals based on their accessibility and on their availability to partake in the study. Such individuals were referred to us by persons that were acquaintances of the research group's members, members who were trained in data collection. We then phoned the persons that were referred to us and invited them to take part in the study. When they accepted our invitation, we scheduled the research group's visits to their homes.

Data Analysis. We analyzed the data via IBM SPSS Statistics software (version 20), employing a statistical significance level of 5\% ( $p$ $\leq .05$ ). Each instrument's psychometric properties (reliability and convergent validity) were assessed. We then performed descriptive analyses (means, standard deviation, percentages) of the overall results. In order to make statistical inferences, criteria relating to parametric assumptions (type of variable, sample size, normality) were analyzed beforehand. We then performed discriminant analysis, which is employed when the dependent variable is dichotomous (in this case, children and adolescents with and without clinical psychological symptoms). The purpose of such analysis is to comprehend the differences between the groups and to predict the participants' likelihood of being assigned to one group or the other (Hair et al., 2005).

\section{Ethical Considerations}

The present study was submitted to and approved by the Research Ethics Committee of the University of Vale do Rio dos Sinos, case number 11/016. An informed consent form (ICF), drafted in accordance with the recommendations of Brazilian National Health Council ruling no. 466/2012 and Federal Psychology Council ruling no. $16 / 2000$, was read to the participants. Consenting participants signed two copies of the ICF, one for the participants themselves; and the other, for institutional records. After the questionnaires were answered, each participant's set was sealed in an envelope along with the ICF in the presence of the participant, in order to preserve the confidentiality of the information.

\section{Results}

We performed descriptive analyses in order to characterize our sample. The participants' ages ranged between 22 and 66 years, with a mean age of 41.81 years $(S D=7.82) .81 .5 \%$ of the examinees were married and $18 \%$ were in a civil union. $91 \%$ of the latter were engaged in their first union, while $8 \%$ had remarried. The duration of such marriages ranged between 4 and 36 years, with a mean duration of 18.26 years $(S D=6.68)$.

With respect to educational level, 22.4\% of the participants had a complete/incomplete elementary/middle school education; 31.6\%, a complete/incomplete high school education; $6.6 \%$, technical training; $28.1 \%$, a complete/incomplete university education; and $11.2 \%$ had taken a graduate course. $88 \%$ of all the examinees reported that they were engaged in paid employment. Their personal incomes were classified into six groups: less than 2 Brazilian minimum-wage salaries (MWS), $21.6 \%$ of the sample; 2-4 MWS, 28.6\%; 4-6 MWS, 15.6\%; 6-8 MWS, 8.5\%; 8-10 MWS, 6\%; and over 10 MWS, 6\%. The participants' average number of children was $1.66(S D=0.70)$, and $91.5 \%$ had from one to two children. The mean age of the children described by the examinees on the questionnaires was 11.3 years $(S D=4.25)$, and those children's gender distribution was $59.5 \%$ males and $40.5 \%$ females.

We employed discriminant analysis for the purpose of identifying which of the 15 variables (which are the dimensions of the scales that make up the study) differentiate the clinical group's children/adolescents from those of the nonclinical group. The scores for behavioral disorders were classified as nonclinical for scores under 
60 and clinical for scores over 60 , as was recommended for research purposes by the instrument's authors (Achenbach \& Rescorla, 2001). Based on this classification, our results reveal that $10 \%$ of the children and adolescents in our sample are considered clinical cases.

The variables we tested were the following: conjugality (marital conflicts, cohesion and adaptability); coparenting (competition, child exposure to coparenting conflicts, agreement, support, responsibility sharing, and coparental approval); parenting (parental encouragement of child autonomy, emotional support/affection, intrusive parenting practices, insistence on responsibility, punitive control and behavioral supervision).

In line with the results shown in Table 2, the cut-off point established for the variables with the greatest explanatory power was $\geq 0.3$ (Sarriera et al., 2012). With respect to the differentiated group, the centroid values $(F)$ were the following: 1.430 for children and adolescents with clinical symptoms and -0.163 for children and adolescents without symptoms. The centroid values indicate that the groups are far from the profile obtained, being differentiated by the variables presented. In the correlations we found, the centroid's proximity indicates the direction favoring one group or the other.

Table 1

Function Values

\begin{tabular}{|c|c|c|c|c|c|c|c|c|}
\hline Function & $\begin{array}{l}\text { Specific } \\
\text { Value }\end{array}$ & $\begin{array}{c}\text { Variance } \\
\text { Percentage }\end{array}$ & $\begin{array}{c}\text { Cumulative } \\
\text { Variance }\end{array}$ & $\begin{array}{l}\text { Canonical } \\
\text { Correlation }\end{array}$ & Wilks $\lambda$ & $X^{2}$ & $d f$ & Sig. \\
\hline 1 & 0.235 & 100.00 & 100.00 & 0.436 & 0.810 & 37.291 & 15 & 0.001 \\
\hline
\end{tabular}

The variables presented in this section are ordered according to their explanatory power for the discriminant analysis, that is, as per the extent to which they are capable of differentiating the clinical group from the nonclinical group; such variables exhibited an explanatory power of $80.6 \%$ for both groups. The results of the discriminant analysis revealed that 10 of the
15 variables displayed a higher value (cut-off point: load value $\geq 0.3$ ) in terms of differentiating the groups. In Table 2, one perceives that the variables associated with coparental competition (0.721), intrusive parenting (0.542), child exposure to coparenting conflicts (0.525), and marital conflicts (0.401) most strongly differentiated children with clinical symptoms.

Table 2

Structure Matrix

\begin{tabular}{lc}
\hline \multicolumn{1}{c}{ Variables } & Function 1 \\
\hline Coparental competition & 0.721 \\
Coparental agreement & -0.679 \\
Intrusive parenting & 0.542 \\
Child exposure to coparenting conflicts & 0.525 \\
Marital adaptability & -0.492 \\
Encouragement of child autonomy & -0.478 \\
Coparenting responsibility sharing & -0.473 \\
Marital conflicts & 0.401 \\
Coparental support & -0.387 \\
Marital cohesion & -0.369 \\
\hline
\end{tabular}




\section{Discussion}

Our results reveal that the coparental competition variable exhibits the greatest discriminant power (i.e., it is the coparenting factor that influences child behavior the most). This finding could signify that the spouses' power struggles or lack of negotiations regarding shared responsibilities and their child's needs have a negative impact on the child's behavior. This finding reinforces the findings of other studies (Blandon et al., 2014; Christopher et al., 2015; Sbicigo \& Dell'Aglio, 2012) concerning the extent to which the coparenting subsystem influences child development.

The intrusive parenting and child exposure to coparenting conflicts variables exhibit similar and equally significant discriminant explanatory power. In this sense, intrusive parenting and the imposition of rules of conduct without discussing them beforehand are parenting methods that can fall short of a child's need for autonomy. Such practices predominantly involve sentiments of intolerance and disrespect that, associated with the child exposure to coparenting conflicts variable, justify its discriminant power. Such correlations reinforce the fact that the hypothesized spillover (Erel \& Burman, 1995) between conjugality and parenting can also occur between coparenting and parenting in the present sample, in which high levels of child exposure to coparenting conflicts appear to be manifested in punitive parenting practices, which in turn leads back to increased levels of coparental conflict and children's psychological symptoms (Gerard et al., 2006; Kwon et al., 2013; Stroud et al., 2011).

Both intrusive parenting and child exposure to coparenting conflicts are correlated with the fourth variable that differentiates children with clinical symptoms. Marital conflicts evidence a couple's difficulties to jointly and constructively manage and solve problems, a fact that influences the parent-child relationship and negatively affects child development via psychological symptoms, as postulated by other researchers (Davies et al., 2002; Einsfeld et al., 2012; Gerard et al., 2006).
The variables related to coparental competition, intrusive parenting, child exposure to coparenting conflicts, and marital conflict significantly distinguished children with clinical symptoms. Such findings partly sustain our second hypothesis, for the coparenting dimension did in fact exhibit the greatest discriminant power, although it was followed by the parenting and conjugality dimensions. Each variable's discriminant power raises certain issues.

If the couple was formed without children, then marital conflict will lead to family problems because it precedes parenthood and co-parenthood. It thus follows that, if the couple develops the ability to resolve marital conflicts prior to commencing parenthood and co-parenthood, this would safeguard child adjustment (Mosmann et al., 2008). In this sense, it is important that intimate partners recognize conflict situations that are difficult to deal with in order to seek help via marriage education programs or through personal, family or couples therapy (Epstein, Warfel, Johnson, Smith, \& McKinney, 2013; Kumpfer \& Brooks, 2010). Commencing parenthood before learning to constructively manage conflicts that could even increase in intensity and frequency due to the difficulties inherent to parenting can be a child-development risk factor. This can happen, considering that the child will be born in an environment in which there are conflicts that will be added to the demands of parenting and of restructuring the family system.

In contrast, the coparental agreement (-0.679), adaptability (-0.492), encouragement of autonomy (-0.478), coparenting responsibility sharing (-0.473), coparental support (-0.387), and marital cohesion (-0.369) variables differentiated children without clinical psychological symptoms. The coparental agreement variable exhibited the greatest discriminant power. This finding relates to the repercussions of the parents' negotiations concerning childcare and parenting responsibilities and to their children's ability to identify such dynamics in the family environment (Mendez et al., 2015; Riina \& McHale, 2015). Such evidence partly sustains our first hypothesis, and it is consistent with 
Feinberg's affirmations (2003) to the effect that coparental agreement is among the principal parent-child mediating strategies, which relate to the effectiveness of parenting methods, when employed homogeneously by the parents.

Adaptability was the second variable that most differentiated children without symptoms. This fact corroborates a wide range of studies (Erel \& Burman, 1995; Gerard et al., 2006; Stroud et al., 2011; Wagner \& Mosmann, 2009) that attribute the conjugality variables' influences to the principal child development-related demands, as a protective factor. While several variables operate as risk factors to the children in this study, a couple's ability to adapt to everyday problems serves as a factor that is protective of their development.

Our finding in relation to the parental encouragement of child autonomy variable, differentiating children without symptoms, differs slightly from the presumptions of Freitas and Piccinini (2010) concerning parenting practices that stand out in relation to a child's socioemotional development and to the equilibrium of the family environment during the various lifecycle phases. Such a difference could be associated with the coparenting subsystem's inclusion in the present study, given that the results we obtained show that this dimension's variables more strongly differentiated the group with and without symptoms. Furthermore, the coparenting responsibility sharing and coparental support variables indicate that a couple's ability to share the responsibility for a child's needs and to support each other when facing unforeseeable parenting situations produces a wholesome interpersonal environment for child development (Scrimgeour et al., 2013).

Cohesion was the third and final variable that differentiated the group without clinical symptoms, thus proving that the emotional connection between spouses is a predictor of child adjustment (Sbicigo \& Dell'Aglio, 2012) and indicating correlations between the family subsystems (Erel \& Burman, 1995; Majdandzic et al., 2012). Emotionally attached couples also exhibit high adaptability levels, a phenomenon that affects coparenting responsibility sharing, coparental agreement and, consequently, the parental practice of encouraging the autonomy of children, who thus do not exhibit psychological symptoms.

We highlight the fact that, in both groups (with symptoms and without symptoms), both of the conflicting coparenting dimensions (coparental agreement and coparental competition) exhibited greater discriminant power, partly supporting our hypotheses and corroborating our findings that the coparenting subsystem strongly influences child development, both positively and negatively (Feinberg, 2003; Lamela et al., 2010). Moreover, it is clear that, although they disagree, couples that are capable of negotiating their differences are also capable of managing coparental agreement.

The present study's results evidence the subsystems' interdependence. One observes that conjugality, coparenting and parenting - by way of the variables that make up each of these three dimensions - were present in both groups (children with and without symptoms), differentiating them based on the cut-off point that was defined for this study. Such a finding contradicts our hypothesis that coparenting outweighs conjugality and parenting (Kwon et al., 2013; Mendez et al., 2015; Scrimgeour et al., 2013), yet it supports the literature's claims (Zahn-Waxler et al., 2008) concerning the complexity of a subject that involves a significant amount of interdependent variables that interact dynamically via subsystems (Morril et al., 2010; Schmidt et al., 2011) within the family system, producing connections of a multi-determined nature and magnitude. This becomes evident when one perceives that the various subsystems' dimensions can contribute both positively, promoting healthy child development, and negatively, supporting the development of clinical symptoms.

\section{Conclusions}

The present study focused on discovering the discriminant role of marital, parental and coparental relationship variables in relation to children and adolescents with and without clinical psychological symptoms. One perceives that 
the three family subsystems that were examined in this article are interdependent in terms of differentiating children with clinical psychological symptoms from children lacking such symptoms. This broader view of the family system, which does not focus exclusively on the parental dyad or on the father-child/mother-child relationship, is becoming increasingly necessary in Western society because paternal involvement is increasingly valued nowadays and because the division of roles has become more flexible, demonstrating that the distribution of parenting responsibilities influences family dynamics. Along these lines, the family system is no longer viewed merely as the sum of its parts (subsystems), but also as a comprehensive system of complex interrelations.

Our results also reveal that the coparenting variables exhibit the greatest power of differentiation between groups, followed by the parenting and conjugality variables. One thus perceives that coparenting acts as an important intervening factor between conjugality and parenthood, for it influences both the relationship between the parents and the child and the relationship between the spouses themselves, and even by way of their overflow, as per the spillover concept.

From this standpoint, numerous contributions can be made to understanding children's symptoms when one observes the parental dyad. One way of sensitizing couples to get in touch with their conflicts is through their children's symptoms, which, as our results indicate, is an approach that denounces the dynamics of the couple. Such symptoms are an auxiliary means for parents to seek help and focus on understanding marital dynamics. It would thus behoove professionals in this area to expand their understanding of such symptoms, embracing a distinct approach to dealing with such cases, whereby the entire family receives professional attention, believing that this form of intervention can produce an effect that is not only curative, but also preventive.

Our results amount to evidence that could help focus such family interventions along the lines of concentrating on coparental competition, intrusive parenting, child exposure to copa- renting conflicts, and marital conflicts. Toward this end, we believe that developing the ability to resolve marital conflicts, investing in protecting children from such difficulties and maximizing coparental support, coparenting responsibility sharing, marital cohesion and spousal adaptability would tend to positively influence the family environment and, consequently, children's mental health.

With respect to the present study's limitations, we point to the fact that the assessment of the children and adolescents' psychological symptoms was based on their parents' perceptions of such symptoms and that such data was obtained exclusively through self-reports. Further studies could add children's views on such phenomena, and observations of family interactions could contribute to expanding knowledge in this area.

\section{Referências}

Achenbach, T. M., \& Rescorla, L. A. (2001). Manual for the Aseba School-Age Forms \& Profiles. Burlington, VT: University of Vermont, Research Center for Children, Youth \& Families.

Blandon, A. Y., Scrimgeour, M. B., Stifter, C. A., \& Buss, K. A. (2014). Within-and between-family differences in cooperative and competitive coparenting. Journal of Family Psychology, 28(1), 106-111. doi:10.1037/a0035266

Bolsoni-Silva, A. T., Paiva, M. M., \& Barbosa, C. G. (2009). Problemas de comportamento de crianças/adolescentes e dificuldades de pais/ cuidadores: Um estudo de caracterização. Psicologia Clínica, 21(1), 169-184. doi:10.1590/ S010356652009000100012

Buehler, C., \& Gerard, J. M. (2002). Marital conflict, ineffective parenting, and children's and adolescents' maladjustment. Journal of Marriage and Family, 64(1), 78-93. doi:10.1111/j.17413737.2002.00078. $\mathrm{x}$

Christopher, C., Umemura, T., Mann, T., Jacobvitz, D., \& Hazen, N. (2015). Marital Quality over the Transition to Parenthood as a Predictor of Coparenting. Journal of Child and Family Studies, 24(12), 3636-3651. doi:10.1007/s10826015-0172-0 
Davies, P. T., Harold, G. T, Goeke-Morey, M. C., \& Cummings, E. M. (2002). Child emotional security and interparental conflict. Monographs of the Society for Research in Child Development, 67(3), 1-115. Retrieved from http://www.jstor. org/stable/3181513

Einsfeld, P., Silva, A. G. M., Trindade, M. T., \& Mosmann, C. P. (2012). Interação conjugal, coparental, parental e sintomas internalizantes e externalizantes dos filhos. In II CICPG - Congresso de Iniciação Científica e Pós-Graduação (p. 639-640). São Leopoldo, RS.

Engle, J. M., \& McElwain, N. L. (2013). Parental depressive symptoms and marital intimacy at 4.5 years: Joint contributions to mothers-child and father-child interaction at 6.5 years. Developmental Psychology, 49(12), 2225-2235. doi:10.1037/a0032450

Epstein, R., Warfel, R., Johnson, J., Smith, R., \& McKinney, P. (2013). Which relationship skills count most? Journal of Couple \& Relationship Therapy, 12(4), 297-313. doi:10.1080/1533269 1.2013 .836047

Erel, O., \& Burman, B. (1995). Interrelatedness of marital relations and parent-child relations: A meta-analytic review. Psychological Bulletin, 118(1), 108-132. doi:10.1037/00332909.118.1.108

Falceto, O. G. (1997). Famílias com desenvolvimento funcional e disfuncional: Validação das escalas diagnósticas Faces III, Beavers - Timberlawn e Avaliação Global do Funcionamento Interacional (Master's thesis, Programa de Pós-Graduação em Medicina: Clínica Médica, Universidade Federal do Rio Grande do Sul, Porto Alegre, RS, Brazil).

Felgosa, M. R. D. L. (2013). Coesão e adaptabilidade familiares: Estudo preliminar das características psicométricas da FACES III numa amostra de mães portuguesas (Master's thesis, Programa de Pós-Graduação em Psicologia Clínica e da Saúde, Universidade do Algarve, Portugal).

Feinberg, M. (2003). The internal structure and ecological context of coparenting: A framework for research and intervention. Parenting: Science and Practice, 3(2), 95-132. doi:10.1207/ S15327922PAR0302_01

Feinberg, M. E., Brown, L., \& Kan, M. L. (2012). A multi-domain, self-report measure of coparenting. Parenting: Science and Practice, 12(1), 1-21. doi:10.1080/15295192.2012.638870
Freitas, A. P. C. O., \& Piccinini, C. A. (2010). Práticas educativas parentais em relação ao filho único e ao primogênito. Estudos de Psicologia (Campinas), 27(4), 515-528. doi:10.1590/ S0103-166X2010000400009

Gerard, J. M., Krishnakumar, A., \& Buheler, C. (2006). Marital conflict, parent-child relations, and youth maladjustment a longitudinal investigation of spillover effects. Journal of Family Issues, 27(7), 951-975. doi:10.1177/0192513X05286020

Hair, J. F., Anderson, R. E., Tatham, R. L., \& Black, W. C. (2005). Análise Multivariada de Dados (5th ed.). Porto Alegre, RS: Artmed.

Holland, A. S., \& McElwain, N. L. (2013). Maternal and paternal perceptions of coparenting as a link between marital quality and the parent - Toddler relationship. Journal of Family Psychology, 27(1), 117-126. doi:10.1037/a0031427

Jia, R., Kotila, L. E., \& Schoppe-Sullivan, S. J. (2012). Transactional relations between father involvement and preschoolers' socioemotional adjustment. Journal of Family Psychology, 26(6), 848-857. doi:10.1037/a0030245

Kumpfer, K. L., \& Brooks, J. (2010). Effective family nurturing programs for the prevention of family violence and child maltreatment. In B. Fisher \& S. Lab (Eds.), Encyclopedia of Victimology and Crime Prevention. Thousand Oaks, CA: Sage.

Kwon, K. A., Jeon, H. J., \& Elicker, J. (2013). Links among coparenting quality, parental gentle guidance, and toddlers' social emotional competencies: Testing direct, mediational, and moderational models. Journal of Family Studies, 19(1), 19-34. doi:10.5172/jfs.2013.19.1.19

Lamela, D., Figueiredo, B., \& Bastos, A. (2013). Perfis de vinculação, coparentalidade e ajustamento familiar em pais recém-divorciados: Diferenças no ajustamento psicológico. Psicologia: Reflexão e Crítica, 26(1), 19-28. doi:http://dx.doi. org/10.1590/S0102-79722013000100003

Lamela, D., Nunes-Costa, R., \& Figueiredo, B. (2010). Modelos teóricos das relações coparentais: Revisão crítica. Psicologia em Estudo, 15(1), 205216. doi:10.1590/S141373722010000100022

Laxman, D. J., Jessee, A., Mangelsdorf, S. C., Rossmiller-Giesing, W., Brown, G. L., \& SchoppeSullivan, S. J. (2013). Stability and antecedents of coparenting quality: The role of parent personality and child temperament. Infant Behavior and Development, 36(2), 210-222. doi:10.1016/j. 
infbeh.2013.01.001

Majdandzic, M., Vente, W., Feinberg, M. E., Aktar, E., \& Bögels, S. M. (2012). Bidirectional associations between coparenting relations and family member anxiety: A review and conceptual model. Clinical Child and Family Psychology Review, 15(1), 28-42. doi:10.1007/s10567-0110103-6

Marsanic, B. V., \& Kusmic, E. (2013). Coparenting within the Family System: Review of Literature. Collegium Antropologicum, 37(4), 1379-1384.

Mendez, L. M. R., Loker, T., Fefer, S., Wolgemuth, J., \& Mann, A. (2015). "Either come together or fall apart": Coparenting young children with challenging behaviors. Couple and Family Psychology: Research and Practice, 4(2), 74-91. doi:10.1037/cfp0000039

Merrifield, K. A., \& Gamble, W. C. (2012). Associations among marital qualities, supportive and undermining coparenting, and parenting selfefficacy: Testing spillover and stress-buffering processes. Journal of Family Issues, 34(4), 510533. doi:10.1177/0192513X12445561

Morril, M. I., Hines, D. A., Mahmood, S., \& Cordova, J. V. (2010). Pathways between marriage and parenting for wives and husbands: The role of coparenting. Family Process, 49, 59-73. doi:10.1111/j.1545-5300.2010.01308.x

Mosmann, C. P., Costa, C. B., Einsfeld, P., Silva, A. G. M., \& Koch, C. (2017). Conjugalidade, parentalidade e coparentalidade: Associações com sintomas externalizantes e internalizantes em crianças e adolescentes. Estudos de Psicologia (Campinas), 34, 487-498.

Mosmann, C., Wagner, A., \& Sarriera, J. (2008). A qualidade conjugal como preditora dos estilos educativos parentais: $O$ perfil discriminante de casais com filhos adolescentes. Psicologia, 22(2), 161-182. Retrieved from http://revista. appsicologia.org/index.php/rpsicologia/article/ view/352

Olson, D. (1986). Circumplex Model VII: Validation studies and FACES III. Family Process, 25(3), 337-351. doi:10.1111/j.15455300.1986.00337.x

Pedro, M. F., Ribeiro, T., \& Shelton, K. H. (2012). Marital satisfaction and partners' parenting practices: The mediating role of coparenting behavior.Journal of Family Psychology, 26(4), 509-522. doi:10.1037/a0029121
Portugal, A., \& Isabel, A. M. (2013). A comunicação parento-filial: Estudo das dimensões comunicacionais realçadas por progenitores e por filhos. Psicologia: Reflexão e Crítica, 26(3), 479-487. doi:10.1590/S0102-79722013000300007

Riina, E. M., \& McHale, S. M. (2013). Bidirectional influences between dimensions of coparentig and adolescente adjustment. Journal of Youth Adolescence, 43(2), 257-269. doi:10.1007/ s10964-013-9940-6.

Riina, E. M., \& McHale, S. M. (2015). African american couples' coparenting satisfaction and marital characteristics in the first two decades of marriage. Journal of Family Issues, 36(7), 902-923. doi:10.1177/0192513X13495855

Rocha, M. M., Rescorla, L. A., Emerich D. R., Silvares, E. F. M., Borsa, J. C., Araújo, L. G. S., ...Assis, S. G. (2013). Behavioural/emotional problems in Brazilian children: Findings from parents' reports on the child behavior checklist. Epidemiology and Psychiatric Sciences, 22(4), 329-338, 1-10. doi:10.1017/ S2045796012000637

Sarriera, J. C., Ximenes, V. M., Bedin, L., Rodrigues, A. L., Schütz, F. F., Montserrat, C., ...Silva, C. L. (2012). Bem-estar pessoal de pais e filhos e seus valores aspirados. Aletheia, 37, 91-104. Retrieved from http://pepsic.bvsalud.org/pdf/ aletheia/n37/n37a07.pdf

Sbicigo, J. B., \& Dell'Aglio, D. D. (2012). Family environment and psychological adaptation in adolescents. Psicologia: Reflexão e Crítica, 25(3), 615-622.

Schmidt, B., Crepaldi, M. A., Vieira, M. L., \& Moré, C. L. O. O. (2011). Relacionamento conjugal e temperamento de crianças: Uma revisão da literatura. Arquivos Brasileiros de Psicologia, 63(3), 89-106. Retrieved from http://pepsic.bvsalud. org/pdf/arbp/v63n3/08.pdf

Scrimgeour, M. B., Blandon, A. Y., Stifter, C. A., $\&$ Buss, K. A. (2013). Cooperative coparenting moderates the association between parenting practices and children's prosocial behavior. Journal of Family Psychology, 27(3), 506-511. doi:10.1037/a0032893

Silva, A. G. M., \& Mosmann, C. (2014). Fatores conjugais, coparentais e parentais como preditores de sintomas internalizantes e externalizantes dos filhos. In XXI Mostra Unisinos de Iniciação Científica e Tecnológica. Anais da Mostra 
Unisinos de Iniciação Científica e Tecnológica (pp. 210-211). São Leopoldo, RS: Casa Leiria.

Stroud, C. B., Wilson, S., Durbin, E. C., \& Mendelsohn, K. A. (2011). Spillover to triadic and dyadic system in families with young children. Jornal of Family Psychology, 25(6), 919-930. doi:10.1037/a0025443

Teixeira, M. A. P., Oliveira, A. M., \& Wottrich, S.H. (2006). Escalas de práticas parentais (EPP): Avaliando dimensões de práticas parentais em relação a adolescentes. Psicologia: Reflexão e Crítica, 19(3), 433-441. doi:10.1590/S010279722006000300012

Wagner, A., \& Mosmann, C. (2009). A promoção da qualidade conjugal como estratégia de proteção dos filhos. In T. Féres-Carneiro (Eds.), Casal e Família: Permanências e rupturas (pp. 169189). São Paulo, SP: Casa do Psicólogo.

Zahn-Waxler, C., Shirtcliff, E. A., \& Marceau, K. (2008). Disorders of childhood and adolescence: Gender and psychopathology. Annual Review of Clinical Psychology, 4, 275-303. doi:10.1146/ annurev.clinpsy.3.022806.091358

Received: 20/05/2016

$1^{\text {st }}$ revision: 02/03/2017

Accepted: 10/03/2017

(C) The Author(s), 2018. Open Access. This article is distributed under the terms of the Creative Commons Attribution 4.0 International License (http://creativecommons.org/licenses/by/4.0/), which permits unrestricted use, distribution, and reproduction in any medium, provided you give appropriate credit to the original author(s) and the source, provide a link to the Creative Commons license, and indicate if changes were made. 